\title{
An Analysis of Basic Needs Price Trend at the Early Times of COVID-19 Pandemic in Rejang Lebong Regency of Bengkulu Province
}

\author{
Raslea Azalia, Putri Suci Asriani*, and Melli Suryanty \\ Department of Agricultural Socio-Economics, Faculty of Agriculture, University of Bengkulu \\ ${ }^{*}$ Coresponding author: putriasriani@gmail.com
}

\begin{abstract}
The first time of COVID-19 came to Indonesia gave impact to some aspects including the Price of basic needs which are the most necessary needs for people. It also affected on some regions especially in Rejang Lebong Regency of Bengkulu Province. This research aimed to analyze basic needs Price trend at the early times of COVID-19 Pandemic in Rejang Lebong Regency of Bengkulu Province. To acknowledge the research objective, this research used trend analysis with a simple linear regression method. Data used were secondary data from Department of Trade, Cooperative, Small and Medium Enterprises, and Rejang Lebong Regency Industries in the form of weekly basic needs Price growth in a time series from January - April 2020 including 18 weekly series. The result showed that there was one basic need commodity, domestic sugar commodity, which had positive trend while curly red chili and dry kernel corn commodities had negative trend.
\end{abstract}

Key words : Trend, Price, Basic Needs, COVID-19 Pandemic.

Citation to this paper should be made as follows:

Azalia, R., P. S. Asriani, M. Suryanty. 2020. An Analysis of Basic Needs Price Trend at the Early Times of COVID-19 Pandemic in Rejang Lebong Regency of Bengkulu Province. Agritropica: Journal of Agricultural Science. 4 (1) : 38-47. DOI: https://doi.org/10.31186/Jagritropica.4.1.38-47.

\section{INTRODUCTION}

The most basic need for people in a country is food. Food availability in sufficient amount and quality is needed to maintain food security. Other essential factors in maintaining food security are the affordable food availability and distribution from price perspective and it safety to be consumed by people in order to fulfill energy needs in daily life. Food is important since the increase of its price may affect the massive decrease of calories and protein consumption (Prabowo, 2014).

To fulfill that basic need, other than getting affected by availability, it is also affected by price factor which is related to people's purchasing power. When the price quite highly increases, some people will complain because it will gain their bylaws. That condition will also take over other needs budget (Engkus, 2017).

People needs on basic needs will continuously increase along with the population growth. Moreover, that escalation can also happen due to certain factors and situations, such as in coming Ramadan month, Eid Mubarak day, or in the beginning of a month where every household stocks basic needs for daily life, and other situations which affect to the increase of basic needs. Nowadays, Indonesia is facing Corona Virus pandemic, which its impacts were very big in many aspects like health, economy, transportation, agriculture, and others. One essential aspect prioritized by the government in this Corona Virus 
pandemic is maintaining food stability and basic needs availability in society since the condition where people must stay at home makes them aware so they won't get lack of basic needs. Hence, the demand on basic needs increases.

The increased demand on basic needs in this pandemic made the food task force Indonesian police requested that a number of basic needs for personal interests are limited. That command is stated in a letter no. B/1872/III/Res.2.1/2020/Bareskrim on March $16^{\text {th }}, 2020$. The limitation is done in order to maintain food stock in pandemic. It is also caused of panic buying by people and the price tends to increase since the demand escalates (Halim, 2020).

Likewise in Bengkulu Province, in order to deal with Corona Virus Pandemic, Bengkulu Governor observed the Indonesian Bureau Logistics warehouse to ensure the distribution of basic needs, especially rice, to low-economy society affected by COVID-19 pandemic. The governor said that Bengkulu province has 200 tons of rice stocked in the Indonesian Bureau Logistics warehouse. There will be more food stock from our Domestic Government Budget, notably for food needs in the coming Ramadan month (Kominfo news 2020). This strategy was done because the price of groceries, especially sugar, had increased in this region. Since Corona Virus came into Indonesia, imported sugar to this region has not distributed well so that sugar is hardly afforded (Usmin, 2020). Due to the case, Bengkulu Province Government make a serious effort to maintain the availability and stability of basic needs price therefore they are enough to fulfill society needs.

Rejang Lebong Regency as one of regencies in Bengkulu Province also gets affected by COVID-19 pandemic which is recently spread in Indonesia, where the transportation access of some regions as the basic needs market of Rejang Lebong started to restricted in order to prevent more Corona Virus transmission. Rejang Lebong Regent also stated that groceries stock in that region is recently enough for people there until several upcoming months. Besides of ensuring that the groceries stock in Rejang Lebong Regency is enough for domestic people there in COVID-19 pandemic until Ramadan month and Eid Mubarak 1441 Hijriyah day, he also asked his people to not stockpile or over-buy for basic needs which can create the price escalation (Muhamad, 2020).

Table 1. Scheme of Basic Needs Price Growth in January-April 2020 in Rejang Lebong Regency

\begin{tabular}{lll}
\hline No. & Price Growth Scheme & \multicolumn{1}{c}{ Commodity } \\
\hline 1. & $\begin{array}{l}\text { Horizontal scheme } \\
\text { (constant) }\end{array}$ & $\begin{array}{l}\text { Rice category, cooking oil category, beef category, chicken meat } \\
\text { category, egg category, green cayenne pepper category, garlic } \\
\text { category, condensed milk category, salt and noodle, peanut } \\
\text { category, fish category, cassava. }\end{array}$ \\
2. & Trend scheme & \begin{tabular}{l} 
Domestic sugar, onion, chili, curly red chili, and dry kernel corn. \\
\hline
\end{tabular}
\end{tabular}

Source: Modified secondary data.

From the table above, it can be seen that basic needs price growth data from the first week of January 2020 until the last week of April 2020 in Rejang Lebong Regency shows mostly horizontal price growth scheme (constant) where the price 
data is fluctuating around the average price of the products. Yet there are some commodities which have trend scheme shown by the significantly continuous and fluctuated price increase or decrease. It can be seen that sensitive commodities with fluctuating price in January-April 2020 may be caused of a certain condition factor during that period.

\section{MATERIALS AND METHODS}

Data used for this research was secondary data of weekly basic needs price growth in a time series of January 2020 April 2020, there were 18 weekly series. Data were taken from Department of Trade, Cooperative, Small and Medium Enterprises, and Rejang Lebong Regency Industries. Data were collected through documentation, a recording technique by recording data which are related to the problem in an instance. Data analysis implemented in this research was trend analysis with a simple linear regression method with an equation of $Y=a+b X(Y$ $=$ price, $\mathrm{a}=$ Constanta, $\mathrm{b}=$ linear regression coefficient, and $X=$ time), where a trend is based on its up or down linearly. The commodity which would be analyzed was specified by the number of effects of independent variable to dependent variable which could be seen from the number of determination variable $\left(\mathrm{R}^{2}\right)$. In this research, the biggest trends were used which was shown by the number of effects of independent variable to dependent variable $\left(R^{2}\right)$ which was more than 50 percent $(>0.5)$. If $\mathrm{R}^{2}$ was more than 50 percent $(>0.5)$, the trend analysis would be conducted. It was because the bigger the determination coefficient value $\left(\mathrm{R}^{2}\right)$ was, the bigger effect of independent variable to dependent variable was (Indriyani, 2017)

\section{RESULT AND DISCUSSION}

\section{Basic Needs Price Trend}

Price trend analysis is an analysis method to do an estimation using various information or data which are observed in a certain period of time so the number of fluctuation can be found out and the factors affecting the changes. In this research, the analyzed data was basic needs price growth in Rejang Lebong Regency in a weekly time series from the first week of January 2020 - the last week of April 2020.

From the data analysis which implemented linear regression trend analysis method with equation of $\mathrm{Y}=\mathrm{a}+\mathrm{bX}(\mathrm{Y}=$ price, $\mathrm{a}=$ Constanta, $\mathrm{b}=$ linear regression coefficient, and $X=$ time), where a trend is based on its up or down linearly. The result shows that there were three commodities which their $\mathrm{R}^{2}$ was bigger than 50 percent $(>0.5)$, they were; domestic sugar, curly red chili, and dry kernel corn. The following is description of this research result about the price trend of domestic sugar, curly red chili, and dry kernel corn commodities.

\section{Domestic Sugar Price Trend}

Domestic sugar is one of basic needs commodities which is stocked and produced in domestic. Yet, in fulfilling people's needs of these sugar commodities, the government needs to import sugar since domestic sugar production is not enough yet to fulfill the demand. Sugar commodity availability closely related to its pricing. Factors affecting sugar pricing was production, storage, and distribution. In this case, the government monitored the stability of pricing factors directly (Heriani, 2020).

Rejang Lebong Regency is one regencies which supplies domestic sugar to fulfill basic needs for society. This commodity is monitored directly by 
Department of Trade, Cooperative, Small and Medium Enterprises, and Rejang Lebong Regency Industries. Recently, domestic sugar is having a quite highly price fluctuation. The result of data analysis of domestic sugar price growth trend in a weekly time series from the first week of January 2020 - the last week of April 2020 in Rejang Lebong Regency.

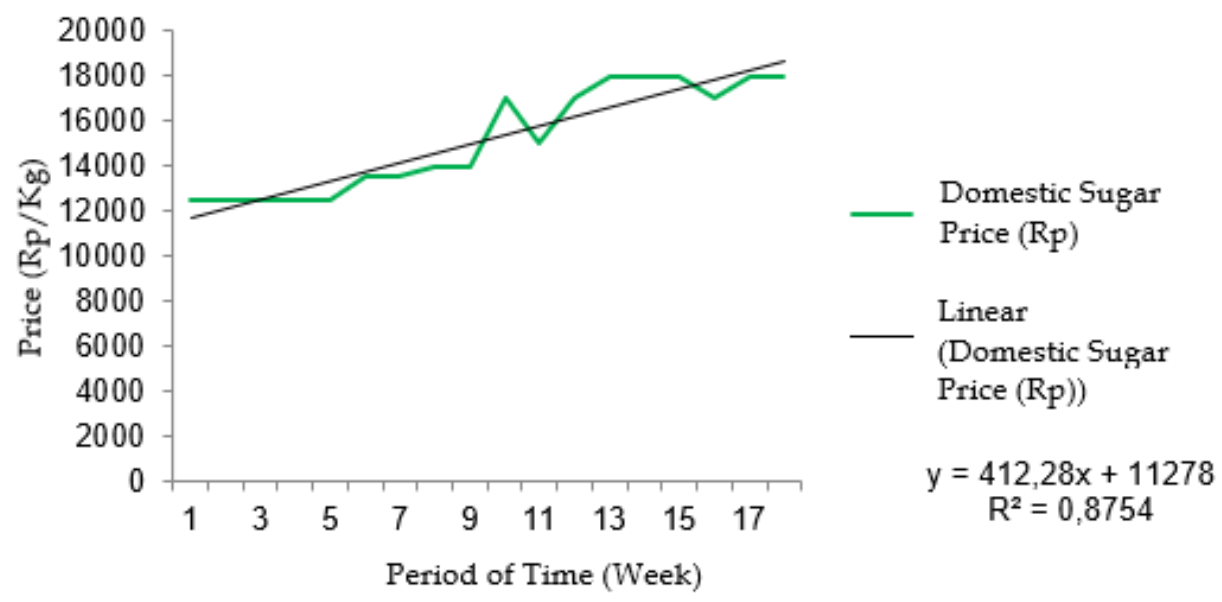

Picture 1. Domestic Sugar Price Trend

From the picture above, it can be seen that the analysis result of domestic sugar price trend in Rejang Lebong Regency from the first week of January 2020 - the last week of April 2020 showed the equation of linear trend as the following:

\section{$\mathrm{Y}=11278+412.28 X$ with $R^{2}=0.8754$ Mean $=15194.44$, Deviation Standard (DS) $=2352.34$}

Interpretation:

a. The Constanta value of 53085 , means that time variable $(\mathrm{X})$ was assumed as constant or zero, therefore curly red chili price (Y) was by Rp53085/week.

b. The coefficient $X$ of 1722.4 means that time variable $(X)$ positively affected curly red chili (Y). If the time variable $(X)$ was increased by one time (1 week), the curly red chili price (Y) would decrease by Rp1722.4/week with an assumption that another independent variable was constant.

c. The $\mathrm{R}^{2}$ value of 0.6852 means that the effect of independent variable time $(X)$ to dependent variable the price of curly red chili (Y) was by 68.52 percent $(0.6852)$, the rest was $31.48 \%$ affected by other factors which were not stated in this research.

From the explanation above, it showed that the price of domestic sugar was extremely affected by its price. With the formed trend, that was positive trend which the growth line increased continuously and fluctuated significantly.

The increased trend was affected by some factors during four months (January - April), one of them was the scarcity of sugar caused by the decreasing production in 2019 since the harvest time was late and COVID-19 pandemic has struck the world, hence the needed import stabilizing the sugar stock was hindered (Ulya, 2020). It can be seen from the picture above that in several first weeks of January, the condition was not much affected by COVID-19 and the sugar stock was still enough to fulfill people's demand so that the price was still averagely stable. In the beginning of February, the price tended to 
rise since people's consumption on sugar increased while its stock started decreasing, therefore in the first week of February 2020, the government recommended import to several importer in domestic to increase the stock of sugar in order to stabilize the price (Yuniartha and Susanto, 2020). Yet, that effort could not make the price decrease in March so that the sugar price was fluctuating, and even it reached the very high price in the middle of March since the stock started decreasing meanwhile the demand was still high. The minister of Trade mentioned that there were a number of people who hampered the sugar stock since there was a growing speculation of sugar import trouble in many countries including in domestic (Lidwina, 2020). Until April, the price was still high. However, the government had the sugar import permission. This import was expected to fulfill the demand in upcoming Ramadan and was able to stabilize the sugar price.

From the data, it can be seen that the minimum price in the first to fifth week was $\mathrm{Rp} 12500 / \mathrm{Kg}$, and then it started increasing until it reached the maximum price $\mathrm{Rp} 18000 / \mathrm{Kg}$ in the $17^{\text {th }}$ and $18^{\text {th }}$ week. This case surely would impact the price in Rejang Lebong Regency. As stated by The Head of the SME Cooperative Trade Office and Industries in Rejang Lebong, Dwi Purnamasari through The District Head of Trade, Sukrial, based on the monitoring result from her side, the sugar price in that region was still high (Mardani, 2020). Based on the case, it was necessary to find out how big the fluctuation of the domestic sugar price growth data in Rejang Lebong Regency since the sugar price considerably tended to continuously rise and fluctuate. The sugar price was much related to the number of stock either domestic or imported. Hence, in this COVID-19 pandemic the risk of the continuous increasing price is big.

\section{Curly red chili Price Trend}

Curly red chili commodity in Rejang Lebong Regency is mostly produced by local farmers in that region. Curly red chili is one of economical commodities for farmers and also as an inflation contributor for economy. The inflation of curly red chili commodity closely relates to the fluctuating chili price.

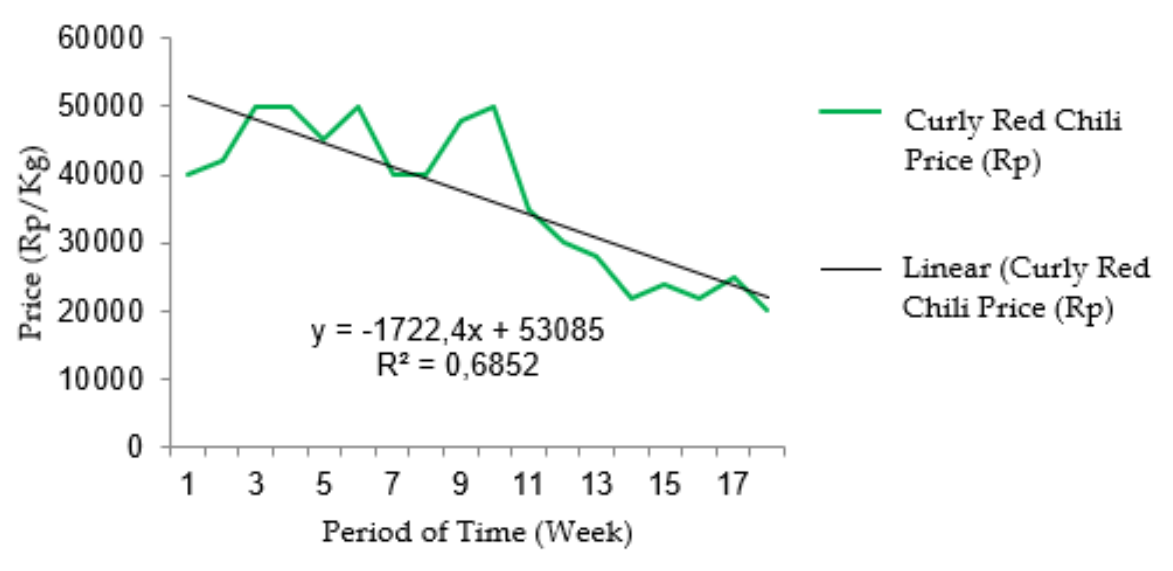

Picture 2. Curly Red Chili Price Trend

Determination of curly red chili price follows the market's mechanism and price reference. The following is the analysis result of curly red chili price 
growth trend in a weekly time series from the first week of January 2020 - the last week of April 2020 in Rejang Lebong Regency.

From the picture above, analysis result data of curly red chili price trend in Rejang Lebong Regency from the first week of January 2020 - the last week of April 2020 resulted an equation linear trend as this following:

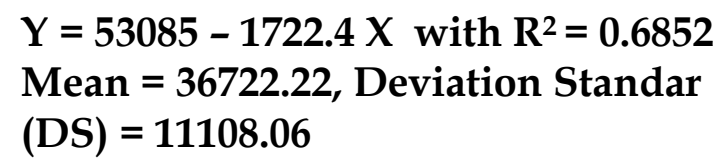

Interpretation:

a. The Constanta value of 53085 means that if the time variable $(X)$ was assumed as constant or zero, the curly red chili price (Y) was Rp53085/week.

b. The coefficient $X$ of 1722.4 means that time variable $(X)$ negatively affected to curly red chili price (Y). If the time variable $(X)$ was increased by one time unit (1 week), the curly red chili price would decrease by Rp1722.4/week with an assumption that other independent variables were constant.

c. The $\mathrm{R}^{2}$ value of 0.6852 means that the effect of independent variable time $(X)$ to dependent variable curly red chili price $(\mathrm{Y})$ was 68.52 percent (0.6852), the rest was 31.48 percent affected by other factors which were not described in this research.

From the explanation above, it showed that curly red chili price was very affected by its price. With the formed trend, negative trend, where the growth line were decreasing continuously and were having a significant fluctuation.

The continuously decreasing and fluctuating trend on curly red chili commodity was affected by several situations during 4 months (JanuaryApril), one of them was the decreasing curly red chili stock because the harvest was not optimal due to rainy season and COVID-19 pandemic which has struck in Indonesia so the distribution of curly red chili was hampered. From the picture above, in January the chili price was still high started from the first week, the price tended to increase since the chili stock was decreasing due to the bad season (Usmin, 2020). In the beginning of February, the price was still high but in the middle of the month, the price started to decrease, then weeks later the price increased again in the beginning of March. In that month, the chili production started escalating. The price was also decreased from in the middle of March until April the line tended to go down. It was because of the effect of Corona Virus diseases in Indonesia, so that the curly red chili could not be sold in closed markets (Muhamad, 2020). It contributed to several farmers who could not continue their career in planting chili since their capital was over to pay debt for seeds, drugs, and fertilizer because their chili could not be sold.

From the data and description above, the fluctuation of curly red chili price in several weeks from the maximum price $\mathrm{Rp} 50000 / \mathrm{Kg}$ decreased linearly until reached the minimum price $\mathrm{Rp} 20000 / \mathrm{Kg}$ in the $18^{\text {th }}$ or last week. This case surely became a problem for the Rejang Lebong Regency government. If the COVID-19 spreading still continued, then transportation and distribution of chili to regions would be hampered, meanwhile chili markets in Rejang Lebong mostly in out of the region. Hence, if the distribution was hampered, there would be chili hoarding which would make the price continuously decrease.

\section{Dry Kernel Corn Price Trend}

Dry kernel corn commodity is mostly produced in Bengkulu Province. Corn quality planted in Rejang Lebong 
and Kepahiang is not good since the production is for young corn not for old corn, and if it is processed into food, the result will be not as good as another corn. Good dry kernel corn is from people's garden along the coast and river like in Kampung Melayu District, Bengkulu City and at some spots in Kaur Regency (Jingga R. 2012). In determining the price of dry kernel corn, it depends on market and production mechanism in a region. The following is the analysis result of dry kernel corn price growth trend in a weekly time series from the first week of January 2020 - the last week of April 2020 in Rejang Lebong Regency.

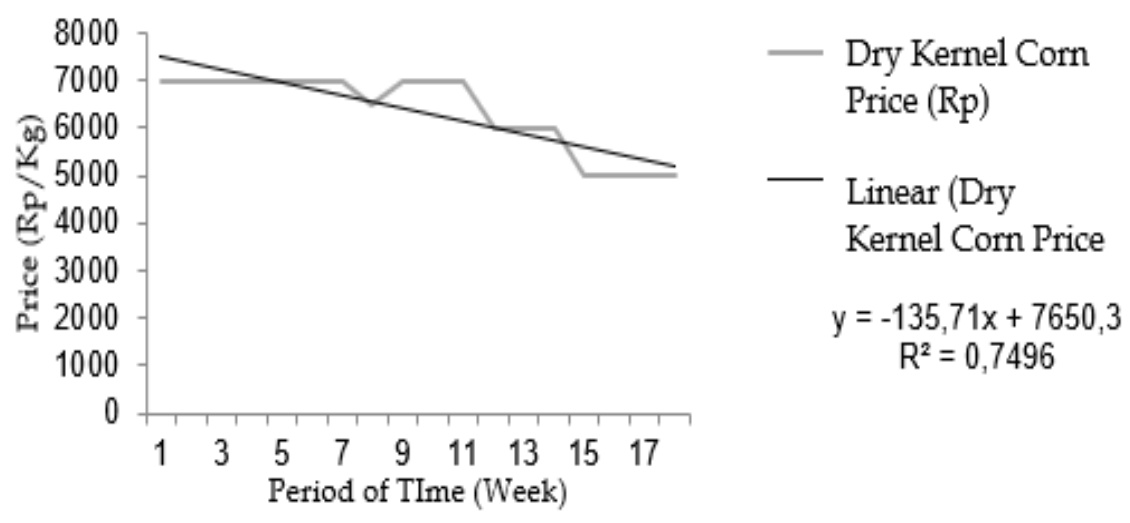

Picture 3. Dry Kernel Corn Price Trend

From the picture above, it can be seen that the result analysis of dry kernel corn price trend in Rejang Lebong Regency from the first week of January 2020 - the last week of April 2020 resulted an equation of linear trend as this following:

$Y=7650.3-135.71 X$ with $R^{2}=0.7496$

Mean $=6361.11$, Deviation Standard (DS) $=836.76$

Interpretation:

a. The Constanta value of 7650.3 means that if time variable $(X)$ was assumed as constant or zero, the dry kernel corn price (Y) was Rp7650.3/week

b. The coefficient $X$ of 135.71 means that time variable $(X)$ negatively affected to dry kernel corn price (Y). If time variable $(X)$ was increased by one time unit (1 week), dry kernel corn price (Y) would decrease by Rp135.71/week with an assumption that other independent variables were constant. c. $\mathrm{R}^{2}$ value of 0.7496 means that the effect of independent variable time $(X)$ to dependent variable dry kernel corn price $(Y)$ was 74.96 percent $(0.7496)$, the rest was 25.04 percent affected by other factors which were not described in this research.

From the explanation above, dry kernel corn price was really affected by its price. The formed trend was negative trend where the growth line was continuously decreasing.

The decreasing trend of dry kernel corn commodity was affected by several factors in four months (January - April), one of them was the decrease of dry kernel corn demand in COVID-19 pandemic therefore there were still many corns which were not sold yet. It can be seen from the picture above that in January, the price was averagely constant right before COVID-19 came to Indonesia, the demand 
was also still stable until the middle of February to the beginning of March although there were price decreasing once. In the middle of March, the price started decreasing since the price at farmers' stage was below the purchase price. The diminished demand on dry kernel corn in COVID-19 pandemic was considered as the main factor of the condition (Timorria, 2020). The price kept decreasing in April. The case was caused by the reduced demand of basic needs for livestock. The stock farmers tended to diminish their production due to the decreasing price of chicken and egg in last two months. Hence, the corn kernel need was also went down.

The decreasing price of dry kernel corn in several weeks from the minimum price of $\mathrm{Rp} 7000 / \mathrm{Kg}$, then started decreasing linearly until it reached the minimum price of $\mathrm{Rp} 5000 / \mathrm{Kg}$ in the $18^{\text {th }}$ or last week. Rejang Lebong Regency surely was one of regions which were affected since the consumers' demand decreased in COVID-19 pandemic for dry kernel corn. If this kept occurring, then the decreasing of the corn price would always happen.

\section{CONCLUSION}

Based on the data analysis of weekly time series from the first week of January 2020 until the last week of April 2020 in Rejang Lebong Regency, it can be concluded that on basic needs price trend, there were three commodities which had positive trend, that was domestic sugar, while curly red chili and dry kernel corn had negative trend.

\section{SUGGESTION}

From the conclusion above, the suggestion can be given for sensitive commodities which are really affected by its price, when the priced tended to increase or decrease. Commodities' price nowadays which will affect the next price should be noticed. To stress the domestic sugar price, the government of Rejang Lebong Regency can maintain its availability by importing and searching other alternatives substituting sugar, such as palm sugar during the COVID-19 pandemic. For curly red chili, the government may find the right solution for distributing abundant chili stock. The last one for dry kernel corn, the government may find the some alternatives for corn marketing so the commodity can be sold.

\section{REFERENCES}

Engkus. (2017). The Implementation of Trade Constitution and Its Implications in Basic Needs Price Control Policy. Journal of Litigation, 18 (1), 1-40.

Halim, D. (2020, April 26). Covid-19 Pandemic, Food Task Force Requested Basic Needs Purchasing to be Limited. Kompas. Retrieved from https://nasional.kompas. $\mathrm{com} / \mathrm{read} / 2020 / 03 / 17 / 13171$ 901/ wabah-covid-19-satgaspangan-minta-pembelian sejumlah-bahan-pokokdibatasi.

Heriani, F. (2020, November 21). ICC Stated That Sugar Price Determining Policy Is Not Appropriate. Hukum Online. Retrieved from https://www.hukumonline. com/berita/baca/lt5ec795e735 055/ kppu-sebut-kebijakanpenetapan-harga-gula-tidak tepat/. 
Indriyani, E. (2017). The Effect of Company Size and Profitability to Company Value. Accountability: Accountancy Journal, 10 (2), 333 $-348$.

Jingga, R. (2012, November 21). Dry Kernel corn price in Bengkulu is still normal. Antara News. Retrieved from https://bengkulu.antaranews. com/berita/6068/hargajagung-pipilan-di-bengkulumasih-normal.

Kominfo News. (2020, April 26). Governor Rohidin Assure 200 Tons of Rice Donation For COVID-19 Impacted People is ready to Be Distributed. Bengkuluprov. Retrieved from https://bengkuluprov.go.id/g ubernur-rohidin-pastikan-200ton-bantuan-beras-untukmasyarakat-terdampak-covid19-siap-didistribusikan/.

Lidwina, A. (2020, November 21). The Increased Trend of Sugar Price in Corona Issue. Kata Data. Retrieved from https://databoks.katadata.co. id/datapublish/2020/03/06/ tren-harga-gula-pasir-naik-ditengah-isu-corona\#.

Mardani, R. (2020, October 23). Stock is Safe, The Sugar Price in Rejang Lebong is still Fluctuating. RmolBengkulu. Retrieved from https://www.rmolbengkulu.c om/read/2020/03/12/22918/ Stok-Aman,-Harga-Gula-PasirDi-Rejang-Lebong-MasihFluktuatif.

Muhamad, N. (2020, April 26). Regent: Groceries Stock in Rejang
Lebong is Sufficient. Antara News. Retrieved from https://bengkulu.antaranews. com/berita/100930/bupatistok-sembako-di-rejanglebong-cukup.

Muhamad, N. (2020, October 23). Chili Farmer in Rejang Lebong Complained about the Low Selling Price. Antara News. Retrieved from https://bengkulu.antaranews. com/berita/106292/petanicabai-rejang-lebong-keluhkanrendahnya-harga-jual.

Prabowo, D.W. (2014). Classification of Basic Needs Commodities with Analytical Hierarchy Process Method. Domestic Trade Policy Center, BP2KP, Ministry of Trade - RI. Jakarta.

Timorria, I. (2020, November 21). Corn Price Decreased, This is The Reason. Ekonomi Bisnis. Retrieved from https://ekonomi.bisnis.com/r ead/20200511/12/1238992/ha rga-jagung-melorot-inipenyebabnya.

Ulya, F. (2020, November 21). The Sugar Price is Increasing, This is the reason. Kompas. Retrieved from https:// money. kompas. $\mathrm{com} / \mathrm{read} / 2020 / 03 / 04 / 05373$ 4326/ harga-gula-melonjakdi- pasaran- ini- penyebabnya? page $=$ all.

Usmin. (2020, April 26). Corona Virus are Strucking, Sugar Price is increasing in Bengkulu. Berita Satu. Retrieved from https://www.beritasatu.com/ nasional/606609 -virus-corona- 
merebak -harga-gula -naik-dibengkulu.

Usmin. (2020, November 21). Curly Red Chili Price in Bengkulu is Escalating. Berita Satu. Retrieved from https:// www.beritasatu.com/ jeismontesori/nasional/594228 Lharga-cabai-kriting-dibengkulu-melonjak.
Yuniartha dan Susanto. (2020, November 21). The sugar stock is 386.065 tons left, this is why the price keeps increasing. Article today line. Retrieved from https:// today. line. $\mathrm{me} / \mathrm{id} / \mathrm{v} 2 /$ article LPJM19M. 